\title{
Tarih Derslerinde Bir Öğretim Materyali: Edebî Ürünler
}

\section{Sezai ÖZTAȘ1}

\author{
$\ddot{O} \mathbf{z}$
}

Destan, hikâye, menkıbe, şiir, roman vb. tarih öğretmenlerinin derslerinde yararlanabilecekleri edebî ürünlerdir. Edebî ürünler, tarih derslerinin sıkıcı olduğunu düşünen ve tarih dersine karşı olumsuz tutum geliştiren öğrencilerin tarih dersine karşı ilgisini uyandırabilecek materyallerin başında gelmektedir. Eğitim sürecinde bilişsel, psikomotor ve duyuşsal öğrenme alanı olmak üzere üç öğrenme alanı bulunmaktadır. Bu öğrenme alanlarından biri olan duyuşsal öğrenme alanını etkileyen önemli unsurlardan biri edebî ürünlerdir. Birçok derste olduğu gibi tarih derslerinde de istenilen düzeyde olmasa da öğretim materyali olarak edebî ürünler kullanılmaktadır. Son yıllarda yapılan bilimsel toplantılarda ve sempozyumlarda, yazılan alan eğitimi kitaplarında tarih öğretiminde edebî ürünlerin kullanılmasının vurgulandığı görülmektedir. Ayrıca ortaöğretim tarih dersi öğretim programlarında da tarih derslerinde edebî ürünlerin önemine vurgu yapılmakta ve tarih öğretmenlerinden derslerinde edebî ürünleri kullanmaları istenmektedir. Bunlara paralel olarak tarih öğretiminde edebî ürünlerin bir öğretim materyali olarak kullanılması artmaya başlamıştır. Bu çalışmanın amacı tarih derslerinde kullanılabilecek edebî türler hakkında bilgi vermektir. $\mathrm{Bu}$ çerçevede öğretme-öğrenme sürecinde kullanılabilecek edebî türler açıllanmakta ve bunların tarih derslerinde nasıl kullanılacağı ve kullanımının önemi üzerinde durulmaktadır. Tarih derslerinde, tarih öğretiminin daha etkili ve verimli gerçekleşmesine katkı sağlayabilecek edebî ürünler kullanılmalıdır.

Anahtar kelimeler: Tarih eğitimi, tarih dersleri, edebî ürün.

\section{An Instructional Material in History Courses: Literary Works}

\begin{abstract}
Sagas, stories, anecdotes, poems, novels etc. are literary works that history teachers can use in their courses. Literary works are the leading materials to arouse students' curiosity for history courses who consider history courses boring and who develop a negative attitude towards history courses. There are three learning areas in the education: cognitive, psychomotor and affective learning. One of the important elements operating in the affective learning area, which is one of these learning areas, is literary works. As in many courses, literary works are used in history courses as teaching materials even if it is not at the desired level. It is seen that the importance of the use of literary works in history teaching is emphasized in books on field education, at scientific meetings and symposiums held in recent years. Furthermore, the importance of literary works in history courses is underlined in the secondary education history course teaching programs, as well and history teachers are asked to use literary works in their courses. In parallel to these, the use of literary works as an instructional material in history teaching has begun to increase. The aim of this study is to instruct about the literary genres that can be used in history courses. In this context, literary genres that can be used in the teaching-learning process are explained, and the importance of their use and the methods to use
\end{abstract}

Dr. Öğr. Üyesi, Kırklareli Üniversitesi, Fen Edebiyat Fakültesi, Tarih Bölümü, sezaioztas@hotmail.com [Makale kayıt tarihi: 4.4.2018-kabul tarihi: 14.4.2018] 
them in history courses are elaborated. In history courses, literary works that can contribute to making history teaching more effective and productive should be used.

Key words: History education, history courses, literary work.

\section{Giriş}

Tarih derslerinin, soyut ve olgu aktarımı esasına dayanan bir anlayışla öğretilmesi, tarih öğretiminde karşlaşılan en önemli problemlerden biridir. Öğrenciler, yaşadıkları dönemden çok uzak zaman dilimleriyle ilgili konular hakkında, genelde sözlü anlatıma dayalı olarak, soyut bir biçimde bilgilendirilmektedir. Bu tarz bir öğretim şekli, bazı öğrencilerin ilgilerini ve meraklarını istenilen düzeyde uyandıramamakta ve derse karşı olumsuz tutum sergilemelerine sebep olmaktadır (Demircioğlu, 2005). Yapılan bazı araştırmalar da öğrencilerin, tarih derslerini sıkıcı ve monoton bir ders olarak algıladıklarından tarih derslerine karşı olumsuz tutum geliştirdiklerini ortaya koymaktadır (Safran, 1993).

Türk tarihi söz konusu olunca, geniş bir alana yayılan Türk tarihini "genişleyen çevreler" anlayışına sığdırarak, açıklamanın kolay olmadığını, farklı mekânlarda ve zamanlarda kurulan farklı Türk devletlerini tutarlı bir şekilde bir plan içinde incelemenin güçleştiğini ifade eden Safran ve Ata (2003), bu konuda iyileştirmenin, ancak alternatif edebî metinlerin kullanılması (okuma parçası, tarihî roman, hikâye vb.) ile öğrencilerin dönemi derinlemesine inceleyebildiği bir ortam oluşturularak yapılabileceğini belirtmektedir. Bu anlamda tarih derslerinde edebî ürünlerin kullanımı, öğrencilerin dönemi derinlemesine inceleyebilmesine fırsat vermesinin yanında derse karşı olumsuz tutumların bir dereceye kadar azalmasını da sağlayabilecektir.

Ortaöğretim Tarih Dersi (9, 10 ve 11. Sinıflar) Öğretim Programı'nda, Ortaöğretim Türk Kültür ve Medeniyet Tarihi Dersi Öğretim Programı'nda ve Ortaöğretim T.C. İnkılâp Tarihi ve Atatürkçülük Dersi Öğretim Programı'nda "tarihsel metinler; tarihin akışı içerisinde insanların eğilimlerini, karşılaştıkları sorunları, yaşadıkları karmaşı dünyayı açıklama gücüne sahiptirler. Öğrenciler; öykü, biyografi, otobiyografi ve benzeri metinleri anlamak için bu metinleri zihinlerinde canlandırarak okuma yeteneğini geliştirmelidir." ve "tarihsel metinleri kavramak, öğrencilerin tarihsel yaklaşım edinmelerini yani geçmişteki olayları yaşandığı dönemin şartları ve kavramlarıyla ele alarak o dönemi yaşayanların bakış açısıyla inceleyebilmelerini gerektirir." (MEB, 2018a; s. 13; MEB, 2018b s. 12; MEB, 2018c; s. 13) ifadelerine yer verilmektedir. Bu anlamda tarih derslerinde edebî ürünlerin önemine vurgu yapılmakta ve tarih öğretmenlerinden derslerinde edebî ürünleri kullanmaları istenmektedir.

Tarih öğretmek için edebiyattan yararlanılması yeni değildir. Vatandaşların erdemli ve iyi karakterlerini barındıran, bireylerin zaferlerini gösteren öyküler 19. yüzyllın okullarının müfredatının merkezindeydi. Son on yılda tarih öğretiminde edebiyatın kullanılması ile ilgili çok sayıda bilimsel ve popüler makale yayımlanmıştır (Nelson \& Nelson, 1999). Yapılan bilimsel toplantılarda ve sempozyumlarda, alan eğitimi kitaplarında tarih öğretiminde edebî ürünlerin kullanılmasının vurgulandığı görülmektedir.

Tarih eğitiminde edebî ürünlerin kullanılması üzerine çeşitli araştırmalar yapılmıştır. Yapılan bu araştırmaların önemli bir bölümünün öğrencilerin ve öğretmenlerin edebî ürünler ile ilgili görüş ve düşüncelerinin belirlenmesi (Çencen, 2010; Er, 2008; Er, 2010; Kaymakçı, 2008; Keskin 2008; Şimşek, 2006a; Şimşek, 2006b) ve tarih öğretiminin edebî ürünlerle desteklenmesinin öğrencilerin akademik başarılarına etkisinin tespit edilmesi (Akkuş, 2007; Bölücek, 2008; Gençtürk, 2005; Kart, 2002; 
Otluoğlu, 2001; Öztürk, 2002; Smith, Monson ve Dobson, 1992; Şimşek, 2000; Şimşek, 2004; Tekgöz, 2005; Top, 2009) amacıyla yapıldığ görülmektedir. Bu araştırmalarda öğrencilerin ve öğretmenlerin edebî ürünler ile ilgili görüss ve düşüncelerinin olumlu olduğu, tarih öğretiminin edebî ürünlerle desteklenmesinin öğrencilerin akademik başarılarını genellikle artırdığı sonuçlarına ulaşılmıştır.

\section{Edebî Ürünler ve Eğitim}

Edebiyat eseri gerçekten olmuş veya olması mümkün yahut sanatçının öyle anlatılmasını benimsediği kişi, durum yahut olayların seçilmiş kelimelerle, ilgi ve heyecan uyandıracak bir şekilde düzenleme ve bütünleştirme (terkip) edilmesi sonucunda oluşan bütünlüktür (Tural, 2000, s. 18). Edebî ürünler, sanatsal bir amaç için yazılmış ya da oluşturulmuş, estetik kaygı güden eserdir. Bir başka ifadeyle, edebiyatın nesnesi, insan hayatının iyi bir ifadesi, bir dil ile temsil edilmesidir (Şimşek, 2015, s. 391).

Kavcar (1999), edebiyat eserlerinin insan, yurt, yaşama ve doğa sevgisiyle insanın iç dünyasını yumuşattığını; iyilik, dostluk, hoşgörü, bağışlama, dayanışma, çalışkanlık, dürüstlük gibi insana özgü tutumları ve değerleri geliştirip pekiştirdiğini; iyiye, güzele ve doğruya yönelme ve yeni değerler kazandırma yolunda telkinlerde bulunduğunu ve insanları bunlar doğrultusunda eğittiğini ifade etmektedir.

\section{Tarih Öğretimi ve Edebî Ürünler}

Bugün bağımsız bir disiplin olan tarih, edebiyatın bir biçimi olarak başlamıştır. 19. yüzyıla gelindiğinde tarihçiler, kendi bilimsel yöntemi ile tarihin bağımsız bir disiplin olduğunu ortaya koymuşlar ve tarih ile edebiyat arasında keskin sınırlar oluşturmuşlardır. Tarih, insanın geçmişteki eylemlerinin, edebiyat ise insanın düşünce ve duygularının kaydıdır. Her iki kayıtda bir diğeri olmaksızın anlaşılamaz. Bir konuya ilişkin derin kavrayışın çok değişik disiplinlerin sunduğu sembolleri çözümlemekle olabildiği unutulmamalıdır. Bir disiplin olarak tarih ile edebiyatın sunduğu dilin imkânları ve sembolleri farklı olup, farklı kavrayışları geliştirmekle birlikte, bu kavrayışlar her iki disiplinin öznesi insan olduğundan ilişkilidir ve birbirlerini pekiştirir (Mansilla, Veronica Boix and Howard Gardner, 1997, s. 381'den aktaran Ata, 2000, s. 159).

İnan'a (1938'den aktaran Ocak, 1997, s. XI) göre edebî ürünler "kazılarda elde edilen çanak çömleklerden daha mühimdirler; çünkü bunlar toprak altında ölü kalan kırıntılar değil, cemiyetin ruhunda binlerce yll yaşayan vesikalardır."

Tarih her yaş evresi ve kültürleşme basamağı için farklıdır ve her hayat basamağı tarihte kendine göre bir şeyler bulmaktadır (Andraess, 1939, s. 8). Andraess, çocuğun tarihi kavramasına yönelik olarak üç gelişim basamağı olduğunu belirtmektedir. Andraess'a göre (1939, s. 10-15) 3-8 yaş arası birinci basamağı teşkil eder ve bu basamağa masal yaşı adı verilir. 9-10 yaş arası ikinci basamağı teşkil eder ve çocuk daha fazla reel konuları tercih eder. Çocuğun yavaş yavaş zaman telâkkisi aydınlanır. Robinson, Güliverin Seyahatleri vb. hikâyelerin verilebildiği bu basamağa Robinson yaşı adı verilir. Çocuğa tarîhi mevzuların 11-12 yaşında verilmesi uygundur. 12-13 yaş arası üçüncü basamağı teşkil eder ve bu basamakta çocuk hakikatleri araştırmaya ve incelemeden hoşlanmaya başlar. Bu yüzden tarihî mevzular bu istikamete yönlendirilerek verilmelidir.

Türkiye'de öğrencilerin zihinleri kompartımanlara bölünmekte ve bu bağlamda interdisipliner bir eğitim verilememektedir. Tarih derslerinde tarih öğretmeni, edebiyat ya da Türkçe öğretmeninin yaşam alanına girmek istememekte, interdisipliner yaklaşımdan kaçınmaktadır. İnterdisipliner yaklaşım; 
değişik bilgi alanları arasındaki ilişkileri vurgulayan, öğrencilerin hayatı bütünüyle görmelerini sağlayan, disiplinler arasındaki iç ilişkileri gösteren, diğer konu alanları ile entegrasyonu mümkün oldukça teşvik eden bir yaklaşım ve öğretim tarzıdır. Son yıllara kadar tarih-edebiyat korelasyonuna, tarih ders kitaplarının ünite sonlarına "tarih okuma parçaları" eklemek dışında pek dikkat çekilmediği bilinmektedir (Ata, 2000, ss. 158-159). Tarih-edebiyat korelasyonunu sağlamak adına tarih derslerinde edebiyatçlardan ve edebî ürünlerden yararlanılarak interdisipliner yaklaşım benimsenmelidir.

Edebî ürünlerin, o devrin insanının değerler sistemine bakışını ve gelecek tasavvurlarını içerdiği için bu durumun zihniyet tarihi araştırmalarında olduğu kadar tarih öğretimi açısından da değer taşıdığını belirten Şimşek (2006c, s. 67), sosyal bilimler öğretimi alanlarına ilişkin çağdaş öğretim ilkelerinin, yaşamın bir bütün olduğu ve ortaya çıkan problemlerin de bütüncül bir bakış açısı ile çözülebileceği anlayışından hareket etmesinin problem çözmede interdisipliner yaklaşımı zorunlu kıldığını, bu bağlamda tarih ve edebiyat alanları arasında var olan bu izolasyonu ve kompartımanlaşmayı gidermeye yönelik düşüncelerin gelişmesine katkı sağladığını, bu sebeple edebî ürünlerin tarih araştırmaları ve eğitimi/öğretimi için birer araç olarak kullanılmasının gündeme geldiğini ifade etmektedir.

Edebî ürünler ve diğer yazllı materyallerin işe koşulduğu öğretim durumlarında, yaparak yaşayarak öğrenen ve bu süreçte, arkadaşlarıyla birlikte araştırma raporları hazırlarken, nihaî kararı vermeden önce, kendilerinde birden çok kaynağı kullanma bilinci ve becerisi gelişen öğrenciler, sorumluluk sahibi birer vatandaş olarak sürdürecekleri gelecek yaşamlarında da bunları kullanabilecektir. Böylece, onların, demokratik bir toplumun, her türlü dogmadan uzak, eleştirel/analitik düşünebilen, inançları ve değerleri inceleyip olumlu tutumlar ve değerler geliştirebilen uyumlu ve etkin bireyler olmaları sağlanabilecektir (Öztürk ve Otluoğlu, 2005, s. 36).

Tarih derslerinde kullanılabilecek birçok edebî ürün bulunmaktadır. Bunlar atasözleri, biyografiler, denemeler, destanlar, efsaneler, fikralar, hâtıratlar (anılar), tarihsel hikâyeler, makaleler, masallar, mektuplar, menkıbeler, romanlar, seyahatnâmeler (gezi yazıları), söylevler (nutuklar), şiirler, türküler, tiyatrolardır. Bu edebî ürünlerin öğretmenler tarafından tarih derslerinde etkili bir şekilde kullanılması öğretimi destekleyecektir.

\section{Tarih Derslerin Kullanılabilecek Edebî Ürünler}

\subsection{Atasözleri}

Türkçe Sözlük'te atasözü, "Uzun deneme ve gözlemlere dayanılarak söylenmiş ve halka mal olmuş söz, darbımesel" (TDK, 1998, s. 100) şeklinde tanımlanmıştır. Kabakçı $(1967$, s. 68) ise atasözünü "halkın yarattığı ve binlerce yıldan beri benimsenerek hayat düsturu edindiği hikmetli, özlü, veciz sözler" olarak ifade etmiştir. Atasözleri öğüt veren ve dersler çıarılmasını sağlayan, toplumdaki bireylerin nasıl hareket etmeleri gerektiğini ifade etmeye çalışan ve toplumun değer yargılarını içeren özlü sözlerdir.

\subsection{Biyografiler}

Biyografi, sanatta, ilimde, politikada ve başka dallarda tanınmış kişilerin, hayatlarını anlatan eserlerdir. Sanatçıyı veya büyük devlet adamını kendisini yetiştiren maddî ve manevî çevre içinde araştıran kişiliğini ve eserlerini birtakım sebeplere ve sonuçlara bağlayan biyografi eserleri, tarihin, edebiyat tarihinin ve tenkidin yardımcılarıdır. Ayrıca ünlü kişilerin hayatları herkes tarafından okunmaya değer ibretlerle doludur (Kabaklı, 1967, s. 528). Biyografi kullanımı öğrencilerin motivasyonunun ve 
başarısının artmasına, büyük insanlara karşı hayranlık ve saygı duymasına, vatanına, milletine ve devletine bağlılık duygularının güçlendirilmesine katkı sağlamaktadır (Er, 2010, ss. 55-56).

\subsection{Denemeler}

Deneme, özgürce seçilen bir konuda gelişen, düşünsel boyutlar içeren, bir konuşma havası içinde biçimlenen, genellikle orta uzunlukta bir düzyazı biçimidir Deneme konuları özgür bir şekilde seçilebilir. Ölüm, sevi, düşünce, özgürlük, doğa sevgisi, alışkanlıklar, giyim kuşam, kadınların saç tuvalleri vb. gibi denemeye konu olabilir. Bu yüzden okurlar; hoşça vakit geçirmek, eğlenmek ve oyalanmak için denemeyi okurlar (Özdemir, 1981, ss. 146-147).

\subsection{Destanlar}

Destanlar, bir soy'a veya soy'un bir boy'una ait tarihî gerçeklerden, bir zaman aralı̆̆ına ait iç ve dış münasebetlerin sonucu olan içtimaî tecrübelerden bir kısmının gerçeğimsi bir tarih hâline dönüştürülerek tahkiyelendirilmesidir (Tural, 1993a, s. 71). Destanlar ve efsaneler, geçmişte yaşamış kişiler ve olaylar hakkında kuşaktan kuşağa sözlü olarak aktarılmış anlatı ve tasvirlerdir (Şimşek, 2010a, s. 258). Milletlerin tarihî vasıfları, ırk özellikleri ve millî değerleri, yaratmış oldukları destanlarda mevcuttur. Oğuz Kağan destanında cihangirlik ve devlet kurma tutkusu, Köroğlu destanında haksızlı̆̆a isyan ve devlete itaat yan yanadır. Bütün Türk destanlarında, iyiliğe, kuvvete, savaşçllığa, biniciliğe, sözde durmaya büyük değer verildiği görülmektedir (Kabaklı, 1967, s. 30).

Destanlar yazıya geçirilmemiş devirlerin tarihlerinin aydınlanmasında bazı ilimlerin yaptığı gibi tarihe yardımcı olmaktadır. Dede Korkut Destanları bunun en güzel örneğidir. Dede Korkut'taki Salur Kazan'ın evinin yağmalandığı destan, Oğuzlar'ın 10. yüzyılda kuzey ve kuzey batı yönünde Kıpçaklar, Peçenekler ve hattâ Hazarlar ile savaştıklarını en eski tarih olaylarının bu destanla alâkalı olduğunu ortaya koymaktadır (Tural, 2000, s. 49).

Aytaş'a (2006) göre destanın edebî ürün olarak kullanılması ile şu amaçlar gerçekleştirilebilir:

Millet olma bilinci,

Zorluklara karşı direnme ve başarma azmi,

Birey olmanın sorumlulukları,

Olağan ve olağanüstülüklerin bir arada kullanılmasının gerekçesi,

Kültürel zenginliklerimiz, maddî ve manevî kültür unsurlarının kaynakları.

\subsection{Efsaneler (Mitler)}

Efsane, ekseriya hakîkî bir temele sahip olan, fakat halk muhayyilesinin ve geleneğinin değiştirmiş ve genişletmiş olduğu bir hikâyedir (Halkın, 1989, s. 16). Mitolojinin "efsaneleri inceleyen ilim dalı" ve "bir milletin fikir ve düşünce tarihi" olduğunu ifade eden Ögel, "Türk mitolojisi, Türk ailesi, Türk cemiyet düzeni ile Türk ahlâk ve âdetlerinin bir aynası gibidir. Türk mitolojisi, diğer dünya mitolojilerinde olduğu gibi, ölü fikir ve düşüncelerden meydana gelmemiştir. Türk mitolojisi, bir hayat yoludur. Cemiyeti düzenleyen ve güden, canlı düşüncelerin bir toplamıdır.” (Ögel, 1997, s. 9) diyerek Türk mitolojisinin önemine vurgu yapmıştır. Efsaneler, çocukların hayal gücünü geliştirirken, bazı tarihsel olayları ve kahramanlıkları ilginç bir anlatımla yansıtmaktadır. Bu özellikleri dolayısıyla efsaneler, bir toplumun ulusal kültürünü gelecek kuşaklara aktarmada büyük önem taşımaktadır. Bu bilinçle tüm 
uluslar, bir yandan bu edebî ürünleri derleyip güncelleştirirken diğer yandan da bunlarla yeni nesilleri tanıştırmaya çalışmaktadır. Efsaneleri yeni nesillerle tanıştıırken ve eğitim ortamında kullanırken olağanüstü/gerçek ötesi unsurlar içerdiklerinden çok dikkatli olunmalıdır. Fakat bu tür edebî ürünler, eski devirlerde toplumların sahip oldukları gelenek ve görenekleri, tutum ve değerleri öğretmek amacıyla yapılacak etkinlikler için zengin malzemeler sunabilir (Öztürk ve Otluoğlu, 2005, s. 103).

\subsection{Fikralar}

Fıkra, birden çok anlama sahip olup "herhangi bir konuyu, belli bir görüş açısından ele alan yazı " ve "güldürücü sonuca bağlanan lâtife" anlamlarına gelmektedir. Bizde gazete fikrasının ilk örneklerini Ahmet Rasim vermiş olup Cenap Şahabettin, Ahmet Haşim, Peyami Safa, Refik Halit Karay, Yusuf Ziya Ortaç, Sabri Esat Siyavuşgil vb. sevilen fikra yazarlarıdır. Türk tarihinde güldürücü sonuca bağlanan fikraların en güzel örnekleri ise Nasreddin Hoca, Bektaşi, İncili Çavuş fikralarıdır (Kabaklı, 1967, s. 538). Tarih derslerinde herhangi bir konuya başlamadan önce o konu ile ilgili bir fikra anlatılması öğrencileri öğretilecek konuya güdülenmesini sağlayacak ve öğrencilerin dikkatlerini konuya çekebilecektir. Ayrıca dersin herhangi bir yerinde, öğrencilerin dikkatlerinin dağıldığı bir zamanda konuya dikkat çekmek için fikra kullanılabilir.

\subsection{Hâtıratlar (Anılar)}

Hâtırat, tanınmış kişilerin geçen ömürleri içinde olup biten olayları güzel bir üslûpla kaleme almalarından doğan bir yazı türüdür (Kabakl, 1967, s. 517). En eski çağlardan itibaren, önemli kişilerin hayatları insanların ilgisini çekmiştir. $\mathrm{Bu}$ eserler, okuyucuların ilgilerinin ve meraklarının giderilmesinin yanı sıra okuyuculara bir dönemin sosyal, ekonomik, politik, kültürel vb. özelliklerini öğrenme firsatı da vermektedir. Tarih öğretmenleri bu ürünleri kullanırken yazarlarının bazı konularda objektif olamayabileceklerini hatırdan çıkarmamalıdırlar (Öztürk ve Otluoğlu, 2005, s. 151-152).

\subsection{Tarihsel Hikâyeler}

Tarihsel hikâyeler, geçmişte gerçekten olmuş, yer, zaman, kişiler ve olaylar açısından gerçek tarihin birer parçasını anlatırlar. Şimşek'e (2015, s. 395) göre tarihsel hikâyeler beş grupta ele alınabilir. Bunlar; şehir ve semtlerin tarihsel hikâyeleri, tarihsel yapı ve anıtların hikâyeleri, tarihsel kişilerin hikâyeleri, nesne-objelerin tarihsel hikâyeleri, tarihsel olay hikâyeleridir. Genç nesillere iyinin ve kötünün anlatılması, bazı toplumsal ve kültürel değerlerin aktarılmasında tarihsel hikâyeler son derece etkilidir (Demircioğlu, 2005, s. 135).

\subsection{Makaleler}

Makale, her konuda bir görüşü savunmak, bir düşünceyi ispatlamak ya da sırf bilgi vermek amaciyla yazılan yazılardır (Kabaklı, 1967, s. 537). Makale, düşünce yazıları içerisinde en önemli edebî türlerden biridir. Makaleyi diğer düşünce yazllarından ayıran en önemli unsur, belli bir düşünceyi delille ve ispatla anlatmasıdır. Makalede anlatım mutlaka gerekçelendirmeli ve bu gerekçelendirme de kanıtlanmalıdır. Makale yazmak için mutlaka bilgi ve birikime ihtiyaç vardır (Aytaş, 2006).

\subsection{Masallar}

Türkçe Sözlük’te masal kelimesi, genellikle halkın yarattığı, ağızdan ağza, kuşaktan kuşağa sürüp gelen, çoğunlukla insanların veya tanrıların başından geçen, olağan dışı olayları anlatan hikâye (TDK, 1988, s. 
992) olarak tanımlanmıştır. Masal, günlük hayatın sınırlı, kuru gerçeğiyle yetinemeyen halk muhayyilesinin tabiat ve gerçekdışı bir âlemde yaşattığı kahramanların hikâyesidir. Adalet, eşitlik, kardeşlik ve mutluluk en katıksız zenginliği ile masal dünyasında bulunmaktadır. Masallarda gam, kasvet, çirkinlik ve âdilik olmayıp iyilik mükâfata kavuşur, kötüler sert ve adaletli bir şekilde cezalandırılır (Kabaklı, 1967, s. 72).

Eğitim tarihinde eğitimcilerin çoğunun çocuklara masallar öğretilmesini ve çocuğun dünyasının masalla zenginleştirilmesini istediklerini ifade eden Kantarcıŏlu (1991), geleneğin çocukla devamlılık kazandığından, geleneğin yaşatılmasında önemli rolü olan masallardan vazgeçilmemesi gerektiğini belirtmektedir.

\subsection{Mektuplar}

Mektup, bir haberi, dileği, arzuyu, istek veya duyguyu, yanımızda olmayan birine iletmek amaciyla hazırlanmış özel yazıdır (Kabaklı, 1967, s. 525). Bir öğretim materyali olarak; toplumun fikri, siyasal ve yönetsel yaşamında yer almış, katkıda bulunmuş ve toplum tarafından kabullenilmiş kişilerin mektuplarından yararlanılmalıdır (Öztürk ve Otluoğlu, 2005, s. 153).

\subsection{Menkıbeler}

Menkıbe, "övülecek iş, hareket ve meziyetler" (Ateş, 1957, s. 701) anlamına gelmektedir. Hz. Peygamber'in ashabının meziyet ve faziletleri, tarihî şahsiyetlerin tercüme-i hâlleri, bazı zümrelerin övgüye değer işleri, bazı mukaddes şehirlerin tasvirlerine de menkıbe denildiği bilinmektedir (Ocak, 1997, s. 27). Menkıbelerden bahseden eserlere de menâkıbnâme denilmektedir.

Batıda da peygamber ve havarileri, Hristiyan manastırları, azizler hakkında söylenen birçok menkıbe mevcuttur. Batıdamenkıbeleri Cizvit tarikatından Jean Bolland ve Gedefroid Henschenius Acta Sanctorum (aziz vesikaları) adıyla toplamış ve yayımlamışlardır (Halkın, 1989, s. 71). Bizde menkıbelerin tarih açısından önemini ilk belirten Fuat Köprülü olmuştur. Fuat Köprülü, Anadolu Selçuklu Tarihinin Yerli Kaynakları (1943) adlı makalesinde menkıbelerin tarihî değerini vurgulamış ve menkıbelerden örnekler vermiştir.

Menkıbelerde tarihî olaylar aynı olmasa bile canlı bir şekilde aktarılır. Menkıbeler, halkın o dönemdeki sosyal yaşamını, gelenek ve göreneklerini verir ve halkın bunları algılayış biçimini de ortaya koyar. Özellikle Osmanlı Devleti'nin kuruluş dönemini içeren tarih kitapları Âşıkpaşaoğlu Tarihi, Oruç Bey Tarihi menkıbelerle doludur. Menkıbeler, toplumların tutum ve ahlâklarını belirleyen referanslarla doludur. Manevî değerlerle yüklü menkıbelerin tarih derslerinde ahlâkî bilgilere karşı çocuğun ruhunun hazırlanmasında etkili olacă̆ı şüphesizdir (Öztaş, 2002).

\subsection{Romanlar}

Roman, "gerçek veya hayalî bir olayın hikâyesi" (Kabaklı, 1967, s. 476) olarak tanımlanabilir. Kabaklı'ya göre (1967, ss. 485-492) konularına göre romanlar 4 çeşittir:

Tarihî roman, konularını tarihte yaşamış kahramanlarla, onları kuşatan gerçek veya hayalî kişilerin hayat ve maceralarından alan romanlardır. 
An Instructional Material in History Courses: Literary Works / S. Öztaş (p. 27-41)

Macera romanı, günlük hayatta her zaman rastlanmayan değişik, şaşırtıcı, beklenmez, esrarlı olayları konu alan romanlardır.

Sosyal roman, yaşanılan toplumu ve o toplumu ilgilendiren dâvaları yeni bir açıdan ele alan, gizli veya açık maksat telkinine çalışan romanlardır.

Tahlil romanı, dış âlemde geçen olaylardan ziyade, kahramanların iç dünyasını ve insan benliğinin kişi ve toplum çatışmaları içindeki belirtilerini konu alan romanlardır.

Tarihî roman, ele aldığı zaman, mekân, insan ve olay unsurları bakımından yazarının şâhidi olmadığı bir dönemi "gerçeğimsi bir hayat" halinde kompozisyonlaştıran edebiyat eseridir (Tural, 1993b, s. 69). Ata (2000, s. 161) "tarihî romanın geçmişi edebî açıdan yeniden inşa etme çabası içerdiğini" ifade etmektedir.

Levstik (1995), tarihî romanların ders kitaplarından daha ilgi çekici olduğunu ve geçmişi daha iyi hayal edebilmelerine yardımcı olduğunu vurgulamıştır. Ata (2000, s. 164) ise tarihî romanların tarih ders kitabının tamamlayıcısı olarak sınıf ortamına getirilmesi önerisinde bulunmakta ve ders kitaplarının ansiklopedik yapısından kaynaklanan sınırlılıklarının, tarihî roman gibi yardımcı araçların sınıf içi etkinliklerde kullanılması ile aşılabileceğini belirtmektedir.

\subsection{Seyahatnâmeler (Gezi Yazıları)}

Yazarın yurt içinde ve yurt dışında yaptığı gezilerde gördüklerini, okurları için ilgi çekici yönlerini özenli bir anlatımla yansıttı̆̆ yazılardır (Özdemir, 1981, s. 178). Seyahatnâmelerde gezilen yerlerin manzaraları, şehirlerin tasvirleri, halkların yaşayışları, kıyafetleri, töre, adet ve gelenekleri, hukuk düzenleri, ahlâk, refah ve iş durumları anlatılır. İlgili seyahatnâmeyi okuyan kişiler, anlatılan yerleri görmüş gibi olurlar ve kendi bakışları ile belki de görüp sezemeyecekleri şeyleri bile yazarın üslûbu ve dikkati sayesinde kavrayabilirler (Kabaklı, 1967, s. 520). Yazdıkları seyahatnâmelerde İbn-i Batuta 14. yüzyıla ait, Evliya Çelebi ise 17. yüzylla ait değerli bilgiler ve ayrıntılar vermekte, yazılan yerler okuyucunun gözünde canlanmaktadır. Yine aynı şekilde 18. yüzyılda Paris ve Berlin'e gönderilen Yirmisekiz Çelebi Mehmet ile Resmî Ahmet Efendi bulundukları şehirlerle ilgili birer sefaretnâme yazmışlardır.

\subsection{Söylevler (Nutuklar)}

Türkçe Sözlük’te söylev (nutuk), bir topluluğa düşünceler, duygular aşlamak amaciyla söylenen, uzunca, coşkulu ve güzel söz, nutuk, hitabe olarak tanımlanmıştır (TDK, 1988, s. 1334). Mustafa Kemal Atatürk'ün söylevleri, Türkiye Cumhuriyeti'nin kuruluş tarih ve ilkelerini gün ışığına çıkarmada kullanılabilecek temel kaynaklardan biridir. Bunlar, ilköğretim okullarındaki sosyal bilgiler, vatandaşlık bilgisi, Türkiye Cumhuriyeti İnkılâp Tarihi ve Atatürkçülük gibi derslerde birer öğretim materyali olarak kullanılabilir (Öztürk ve Otluoğlu, 2005, s. 144).

\subsection{6. Şiirler}

Şiir, zengin sembollerle, ritimli sözlerle, seslerin uyumlu kullanımıyla ortaya çıkan edebî anlatım biçimi (TDK, 1988, s. 1386) olarak tanımlanmaktadır. Konu ve temalarına göre şiirler aşağıdaki şekilde adlandırılabilir (Aytaş, 2006): 
Lirik şïr, etkileyicilik bakımından hüzün, sevgi, sevinç, acı, keder vb. duygulara dayalı durumları yansıtır. His ve hayal unsurları bakımından zengindir. Diğer şiirler içinde de lirizm mutlaka vardır. Fakat lirik şiiri diğerlerinden ayıran temel özellik, onun bir amaca bağlı kalınarak yazılmamış olmasıdır. Lirik şiirin temel amacı, duygulara hitap etmesi ve duyguları dile getirmesidir.

Pastoral şür doğayı ana kavram olarak ele alan ve amacı sadece doğayla ilgili gözlemleri anlatmak olan şiirlerdir. Bir şiirin pastoral olabilmesi için mutlaka gözleme dayalı olması gerekir. Gözlenen olay anlatılmalıdır. Şiirde doğa temel amaç olmalıdır. Doğa unsurları araç olarak kullanılmayacak, doğanın gerçeği anlatılacaktır.

Didaktik şür, tamamen bir ders vermeyi ve bir sonuç çıarmayı amaçlayan şiirlerdir. Nükte şiirler olarak da bilinmektedir. Bu bakımdan insanlara dolaylı yoldan ders verir. Fablların, fikraların nazım söyleyişleri didaktik şiire örnektir. Bir ana fikir etrafında oluşturulmuştur. Çocuklara yönelik yazılan şiirlerin büyük bir kısmı didaktik tarzdadır.

Epik şïr, genellikle olağanüstü bir üslûp ve destansı bir tarzla kaleme alınmış eserlerdir. His ve hayal unsuruna daha az yer verilir. Teması kahramanlık oluğu gibi, başka konular da olabilir. Üslubundan hareketle epik şiiri tespit etmek gerekir. Epik şiire bir anlatım şekli de diyebiliriz. Heyecanlı ve coşkulu bir anlatımı vardır.

Dramatik şïr, eğer bir olay anlatılıyorsa ve bir olaya bağlı olarak duygular alınmışsa o şiirlere dramatiktir demek mümkündür. Genellikle, acıklı ve korkunç olayları anlatan şiirler için verilen bir ad olmakla birlikte, dram aslında bir canlandırma olduğu için, dramatik şiirleri bir durumu canlandırmaya aracı olan şiirler olarak adlandırmak gerekmektedir.

Yazın tarihçilerine, eleştirmenlere ve kimi kuramcılara göre tüm yazınsal yaratılar şiirden doğmuştur (Özdemir, 1981, s. 33). İnsanlık tarihinde tarihsel bilgi, akılda kalması ve gelecek nesillere aktarılabilmesi için nesir olarak değil de şiirsel ifade tarzında kurgulanmıştır (Ata, 2001).

Şiir ezberleme ve şiiri derste etkili bir biçimde kullanma salt Türkçe ve edebiyat derslerine bırakılmamalıdır. Sınıf öğretmeni, sosyal bilgiler öğretmeni ve tarih öğretmeni, Sosyal Bilgiler ve Tarih derslerinde çocukların düzeyine uygun yazılmış şiirleri ezberletilebilir. Lise düzeyinde öğrenciler, kelime hazinesi daha geniş ve düzeyi daha yüksek şïrleri yorumlayabilmeli, açıklamayabilmeli ve çözümlemelidir (Ata, 2001).

Şiirlerin tarih derslerinde kullanımı; öğrencileri konuya motive etmede ve duygularını harekete geçirmede, öğrencilerin empati yapmalarında ve derse aktif katılımlarını sağlamada öğretmenlere yardımcı olmaktadır (Öztaş, 2009).

\section{4 .17. Türküler}

Türkü, olağanüstü, tabiat dışı vakalara ve kişilere yer vermeyen, daha çok ferdî ve sosyal hâdiselere dayanan, bir olayı hikâye etmekten ziyade hâdise karşısındaki içli duyguları tepkileri dile getiren eserlerdir (Kabaklı, 1967, s. 62). Halk ümidini, ümitsizliğini, isyanını, isteğini, anlatmak istediklerini genellikle ozanları aracılığıyla, onların türküleriyle dile getirmiştir (Öztürk ve Otluoğlu, 2005, s. 117). Bölücek (2008) yaptığı çalışmada türkülerle destekli eğitimin öğrencilerin başarılarını artırmada önemli bir etkisi olduğu, ders aracı olarak türkülerin öğrencilerin motivasyonunu, konular arasında bağlantılar kurulmasını ve öğretilen bilgilerin öğrencilerin zihninde kısmen canlanmasını sağladığı 
sonucuna ulaşmıştır. $\mathrm{Bu}$ anlamda tarih derslerinde halkın kültürünü, duygularını, tepkilerini, sevinçlerini yansıtan bu edebî türün tarih derslerinde kullanımı yaygınlaştırılmalıdır.

\subsection{Tiyatrolar}

Tiyatro, oyun, oyuncu, sahne ve izleyici gibi temel ögelerden oluşan sanat; dramatik metin, oyunculuk, sahneleme, sahne tasarımı, sahne giysisi, sahne müziği, ışıklama ve sahne tekniği ögelerinin tümünü birlikte içeren sanatsal etkinliktir (Çalışlar, 1995, s. 631).

Tiyatro eserlerinin sahip olduğu kişi, olay, yer ve zaman bağlantısı, tiyatro eserlerine birçok hedef ve davranışı gerçekleştirmek için uygun bir araç olma özelliğini kazandırmaktadır. Özellikle tarihsel kişilikleri tanıma, siyasal ve toplumsal olay ve yaşantıları öğrenmede öğrencilere yardımcı olabilmektedir (Öztürk ve Otluoğlu, 2005, ss. 145-146).

\section{Tarih Derslerinde Ebebî Ürünler Nasıl Kullanılmalıdır?}

Tarih derslerinde edebî ürünlerin kullanımı belli bir planlama çerçevesinde gerçekleştirilmelidir. Konuya ve kazanımlara göre uygun edebî ürünlerin seçimine dikkat edilmeli, derste edebî ürünler kullanılırken mümkün olduğunca öğrencileri aktif hâle getirecek etkinlikler gerçekleştirilmeli, kullanım sonrasında değerlendirmeler yapılmalıdır.

\subsection{Tarih Derslerinde Kullanılabilecek Edebî Ürünlerin Seçimi}

Tarih derslerinde kullanılabilecek uygun edebî ürünlerin seçimi istediğimiz kazanımların gerçekleşebilmesi için son derece önemlidir. Bu anlamda edebî ürünlerin seçimi çok önemlidir. Tarih derslerinde öğrenme-öğretme sürecinde kullanılacak edebî ürünlerin seçimine yönelik göz önünde bulundurması gereken ölçütler aşağıdaki tabloda verilmiştir:

Tablo 1. Edebî Ürünlerin Seçimine Yönelik Ölçütler

\begin{tabular}{|c|l|}
\hline İLGILİ ÖLÇÜT BOYUTU & \multicolumn{1}{c|}{ BULUNMASI GEREKEN ÖZELLİKLER } \\
\hline \multirow{2}{*}{ Eğitim ve Öğretim Programı } & $\begin{array}{l}\text { Türk Millı̂ Eğitimi'nin genel amaçlarına uygunluk } \\
\text { İlgili öğretim programının genel amaçlarına uygunluk } \\
\text { İlgili öğrenme alanına uygunluk } \\
\text { İlgili kazanıma uygunluk } \\
\text { Öğrencilere kazandırılması gereken beceri ve değerlere uygunluk }\end{array}$ \\
\hline \multirow{3}{*}{ Öğrenci } & $\begin{array}{l}\text { Öğrencinin içinde bulunduğu gelişim dönemine uygunluk } \\
\text { Öğrencinin hazır bulunuşluk düzeyine uygunluk } \\
\text { Öğrencinin ilgi düzeyine uygunluk } \\
\text { Öğrencinin cinsiyetine uygunluk } \\
\text { Öğrencinin ihtiyaçlarına uygunluk } \\
\text { Öğrenci için anlamllık } \\
\text { Sözcük dağarcı̆̆ını geliştirmeye uygunluk }\end{array}$ \\
\hline & Gerçeğe yakınlık \\
\hline
\end{tabular}




\begin{tabular}{|c|l|}
\hline \multicolumn{1}{|c|}{ İçerik } & $\begin{array}{l}\text { Basit, sade ve anlaşılabilirlik } \\
\text { İlgili içeriğe uygunluk } \\
\text { İlgi çekicilik } \\
\text { Olumlu tutum ve davranışlara yönlendiricilik } \\
\text { Şiddet ögeleri içermeme } \\
\text { Duygu, düşünce ve hayal gücünü geliştiricilik }\end{array}$ \\
\hline Dil ve Anlatım & $\begin{array}{l}\text { Anlatım tekniğinin yaş seviyesine uygunluğu } \\
\text { Dilin, sade ve anlaşılabilir olması } \\
\text { Cümlelerin uzunluğunun uygunluğu } \\
\text { Cümlelerin kuruluş biçimleri }\end{array}$ \\
\hline
\end{tabular}

(Top, 2009, ss. 23-24)

\section{2. Tarih Derslerinde Edebî Ürünlerle Yapılabilecek Bazı Etkinlikler}

Tarih derslerinde edebî ürünler çerçevesinde yapılabilecek bazı etkinlikler şu şekilde sıralanabilir:

Edebî üründen ne öğrendikleri öğrencilere sorularak pekiştirme yapılabilir. Sorulacak soruların, hedeflenen davranış değişikliklerinin oluşup oluşmadığını görmek adına davranış değişikliğine yönelik sorular olmasina dikkat edilmelidir.

Anlattıklarının resmedilmesi istenebilir. Bu faaliyet öğrencilerin yaratıcı güçlerini geliştirebilir.

Edebî üründe yer alan kültür unsurlarını (değerler, toplum yapısı, ilişkiler, ekonomik faaliyetler vb.) fark etmeleri istenebilir.

Bazı edebî ürünlerde gerçekler örtülerek geldiği için var olan olağanüstü olayları gerçek olaylardan ayırarak tespit etmeleri istenebilir.

Edebî metinde geçen tarihî olayla ilgili 3-5 dakika bir şeyler yazmaları istenebilir.

Edebî ürünün bazı bölümleri kasten tamamlanmamış ise öğrenciden eksik bırakılan bu bölümleri tamamlamaları istenebilir.

Müzik parçalarından marşlar, türküler, anlatılacak edebî ürünün bazı bölümlerinde kullanılabileceği gibi fon olarak da düşük sesle çalınabilir.

Edebî ürüne ilişkin “Öğrenciler ne biliyor? Ne öğrenmek istiyor? Ne öğrenmişler?” gibi soruların cevaplandı ̆̆ı birer kart, öğrencilerle birlikte hazırlanabilir.

Edebî ürünün ahlâki, düşünsel ve empatik değerlendirmesi yapılabilir.

Edebî üründeki kelimelerin etimolojisi inceletilebilir.

Edebî ürünün bazı yerleri öğrencilere dramatize ettirilebilir. 
Edebî metinde geçen yer adları haritadan buldurularak harita bilgilerinin gelişmesine yardımcı olunabilir.

Konuya ilişkin olayla ilgili olgu toplamaları için bir araştırma yaptırılabilir.

Edebî ürünü geçtiği döneme ilişkin poster, resim, gazete veya dergiler sınıfa getirilerek ilgili dönem hakkında öğrencilerin fikir yürütmeleri ve döneme ilişkin farklı bakış açılarını görmeleri sağlanabilir.

Edebî metinde geçen tarihî olaya ilişkin diğer kurgusal olmayan kitaplar önerilebilir.

Yapılan sınıf içi çalışmayı tamamlamak amacıyla edebî metinin geçtiği tarihî mekâna, edebî metinde adı geçen eşyaların bulunduğu müzeye gezi düzenlenebilir (Ata, 2000, ss. 163-164; Cevat, 2000; ss. 38-39; Çencen, 2010, ss. 64-66; Demircioğlu, 2005, s. 142; Öztaş, 2002; s. 71; Şimşek, 2010a, s. 262; Şimşek, 2010b s. 269)

\section{3. Tarih Derslerinde Edebî Ürünleri Kullanmanın Yararları}

Tarih derslerinde edebî ürünlerin yararları şu şekilde sıralanabilir:

Öğrencilerin eleştirel düşünme, iletişim, zaman ve kronolojiyi algılama okuma ve yazma becerilerinin geliştirilmesine yardımcı olur.

Tarih bilincine sahip olan genç kuşakların çağa uyum sağlamalarına zemin hazırlar.

Farklı bakış açılarının analiz edilmesini sağlayarak, geleneksel ders kitaplarında eksik olan çoklu bakış açısının gelişmesini destekler.

Kültür aktarımının gerçekleşmesini kolaylaştırır.

Daha çok tarihî ayrıntı, ana fikir ve miktarca çok daha fazla tarihî bilgi edinmeyi sağlar.

Soyut konu ve kavramların somutlaştırılmasını sağlar.

Duyuşsal hedeflerin gerçekleşmesini kolaylaştırır.

Geçmişte yaşamış insanlar gibi düşünmelerine ve hissetmeye yardımcı olarak empati kurmasını sağlar.

Yurt ve ulus sevgisi uyandırır.

Eleştirel/analitik düşünmeye, inançlar ve değerleri inceleyip olumlu tutum geliştirmeye yardımcı olur.

Yüksek insanî vasıflar kazandırır.

Derse motivasyonunu ve akademik başarıyı artırır.

Öğrencilerin derse karşı tutumlarını olumlu yönde etkiler.

Tarihî mirasa karşı takdir geliştirmeye ve onları korumaya yardımcı olur. 
İyiye, doğruya, güzele yönelme ve yeni değerler kazandırma yolunda telkinlerde bulunur.

Tarihsel bilgilerin daha kolay hatırlanmasına yardımcı olur.

Eğlenceli bir şekilde tarihî olguları öğretebilir.

Yerel tarihin anlaşılmasını sağlar.

Karakter eğitimine katkıda bulunur (Akkuş, 2007, ss. 112, 127-128; Ata, 2000, s. 164; Çencen, 2010, ss. 7-8, 24-25; Öztaş, 2002, s. 71; Öztürk ve Otluoğlu, 2005, ss. 36-37; Şimşek, 2006c, ss. 73-74).

\section{Sonuc}

Tarih öğretmenleri, sadece ders kitabındaki edebî ürünleri kullanmakla yetinmemeli, konuya uygun edebî ürünleri de sınıfa getirerek derslerinde edebî ürünlerden yararlanma yoluna giderek interdisipliner bir yaklaşım benimsemelidir. Edebî ürünler, tarih derslerini daha zevkli bir hâle getirebilecek ve değişik etkinliklerin yapılabilmesine imkân verebilecek materyallerdir. Bu etkinlikler çerçevesinde edebî ürünlerin tahlil edilmesi, öğrencilere eleştirel düşünme başta olmak üzere birçok beceriyi kazanma firsatı verecektir. Edebî ürünlerle desteklenen öğretim yaklaşımının öğrencilerin akademik başarısını artırmada ve duyuşsal kazanımları sağlamada daha etkili olmasının yanı sıra öğrencilerin derse karşı tutumlarına da olumlu etki yaptığı araştırmalarla ortaya konmuş olduğu gerçeğinden hareketle edebî ürünlere tarih derslerinde yer verilmelidir.

Tarih dersi öğretim programlarındaki kazanımların daha kalıı bir şekilde elde edilebilmesi için hangi kazanımda hangi edebî ürünlerin kullanılabileceği tespit edilmeli ve bu edebî ürünlerin listesi ders kitaplarına konulmalıdır. Tarih öğretmenlerine edebî ürünlerin tarih öğretiminde kullanılmasının ders verimliliği bakımından etkisi açıklanmalı, bu edebî ürünlerden nasıl istifade edecekleri konusunda bilgi verilmeli ve tarih derslerinde edebî ürünlerden yeterince yararlanabilmeleri sağlanmalıdır.

\section{Kaynakça}

Andraess, E. (1939). Çocuğa Uygun Tarih Tedrisatı (Çev. K. Kaya). İstanbul: Tan Matbaası.

Akkuş, Z. (2007). Tarih Öğretiminde Edebi Ürün Kullanımının Öğrenci Başarısına Etkisi. Yayınlanmamış Doktora Tezi, Atatürk Üniversitesi Sosyal Bilimler Enstitüsü, Erzurum.

Ata, B. (2000). Tarih Öğretiminde Bir Araç Olarak; Tarihi Romanlar. Türk Yurdu. 153-154, 158-165.

Ata, B. (2001). Çanakkale Savaşlarını Nasıl Öğreteceğiz?. Türk Yurdu, 21 (164), 23-29.

Ateş, A. (1957). Menâkıp. İslam Ansiklopedisi. C. VII içinde (ss. 701-702). İstanbul: Maarif Basımevi.

Aytaş, G. (2006). Edebî Türlerden Yararlanma. Milli Ĕ̆itim, 169, 261-276.

Bölücek, B. (2008). Sosyal Bilgiler Öğretiminde Türkülerden Yararlanmanın Öğrencilerin Akademik Başarısına Etkisi. Yayınlanmamış Yüksek Lisans Tezi, Gazi Üniversitesi Eğitim Bilimleri Enstitüsü, Ankara.

Cevat, A. (2000). Çocuklara Hikâye Anlatmak Sanatı. İstanbul: Milli Eğitim Bakanlığı.

Çalışlar, A. (1995). Tiyatro Ansiklopedisi. Ankara: T.C. Kültür Bakanlığı.

Çencen, N. (2010). 11. Sinıf Türkiye Cumhuriyeti İnkllap Tarihi ve Atatürkçülük Dersinde Tarih Öğretmenlerinin “Edebi Ürün” Kullanımına İlişkin Görüşleri. Yayınlanmamış Doktora Tezi, Gazi Üniversitesi Eğitim Bilimleri Enstitüsü, Ankara. 
Demircioğlu, İ. H. (2005). Tarih Öğretiminde Öğrenci Merkezli Yaklaşımlar. Ankara: Anı.

Er, H. (2008). İlköğretim öğrencilerine sosyal bilgiler eğitiminde biyografi öğretimi çerçevesinde Atatürkün hayatı nasıl anlatılmalıdır? Uluslararası Sosyal Bilimler Eğitimi Sempozyumu Bildiriler Kitabı içinde (ss. 388-394). Çanakkale: Çanakkale Onsekiz Mart Üniversitesi.

Er, H. (2010). Sosyal Bilgiler Eğitimi Kapsamında İlköğretim Öğrencilerinin “Biyografi” Kullanımına İlişkin Görüşleri. Yayımlanmamış Doktora Tezi. Gazi Üniversitesi Eğitim Bilimleri Enstitüsü, Ankara.

Gençtürk, M. (2005). Tarih Öğretiminde Biyografi Kullanımı. Yayınlanmamış Yüksek Lisans Tezi, Gazi Üniversitesi Eğitim Bilimleri Enstitüsü, Ankara.

Halkın, L. (1989). Tarih Tenkidinin Unsurları (Çev. B. Yediyıldız). Ankara: Türk Tarih Kurumu.

Kabaklı, A. (1967). Türk Edebiyatı. C. I. İstanbul: Türkiye Basımevi.

Kantarcıŏ̆lu, S. (1991). Eğitimde Masalın Yeri. İstanbul: Milli Eğitim Bakanlığı.

Kart, Ö. (2002). Eski Türk Destanlarının Tarih Öğretimindeki Yeri ve Kullanımı. Yayınlanmamış Yüksek Lisans Tezi, Selçuk Üniversitesi Sosyal Bilimler Enstitüsü, Konya.

Kavcar, C. (1999). Edebiyat ve Eğitim. Ankara: Engin.

Kaymakçı, S. (2008). İlköğretim Öğrencilerinin Atatürk'ün Gençliğe Hitabesi'ni Anlama ve Tarihi Olaylarla İlişkilendirme Düzeyine Bir Bakış. Uluslararası Sosyal Bilimler Eğitimi Sempozyumu Bildiriler Kitabı içinde (ss. 388-394). Çanakkale Onsekiz Mart Üniversitesi.

Keskin, S. (2008). Romanlarla Tarih Eğitimi ve Öğretimi. Yayınlanmamış Yüksek Lisans Tezi, Selçuk Üniversitesi Sosyal Bilimler Enstitüsü, Konya.

Levstik, L. (1995). Narrative Constructions: Cultural Frames for History. The Social Studies, 86(3), 113116.

MEB (2018). Ortaöğretim Tarih Dersi (9, 10 ve 11. Sinfflar) Tarih Dersi Öğretim Programı. http://mufredat.meb.gov.tr (Erişim Tarihi: 02.03.2018).

MEB (2018b). Ortaöğretim Türk Kültür ve Medeniyet Tarihi Dersi Öğretim Programı. http://mufredat.meb.gov.tr (Erişim Tarihi: 02.03.2018).

MEB (2018c). Ortaöğretim T.C. İnkılâp Tarihi ve Atatürkçülük Dersi Öğretim Programı. http://mufredat.meb.gov.tr (Erişim Tarihi: 02.03.2018).

Nelson, L. R., ve Nelson, T. A. (1999). Learning history through children's literature. ERIC Digest. https://files.eric.ed.gov/fulltext/ED435586.pdf (Erişim Tarihi: 28.02.2018).

Ocak, A. Y. (1997). Kültür Tarihi Kaynağı Olarak Menâkıbnâmeler: Metodolojik Bir Yaklaşım, Ankara: Türk Tarih Kurumu.

Otluoğlu, R. (2001). İlköğretim Okulu 5. Sinff Sosyal Bilgiler Öğretiminde Yazılı Edebiyat Ürünlerini Ders Aracı Olarak Kullanmanın Duyuşsal Davranış Özelliklerini Kazanmaya Etkisi. Yayınlanmamış Yüksek Lisans Tezi, Marmara Üniversitesi Eğitim Bilimleri Enstitüsü, İstanbul.

Ögel, B. (1997). Türk Mitolojisi I. Ankara: Türk Tarih Kurumu.

Özdemir, E. (1981). Yazı ve Yazınsal Türler. İstanbul: Karacan.

Öztaş, S. (2002). Tarih Eğitiminde Menkıbelerin Yeri ve Önemi, Türk Yurdu, 22(175), 68-72.

Öztaş, S. (2009). Tarih Öğretiminde Şiirlerin Yeri ve Önemi. Uluslararası 5. Balkan Eğitim ve Bilim Kongresi “Günümüzde Balkanlarda Eğitim”, Trakya Üniversitesi 1-3 Ekim 2009 Edirne, Türkiye, C. 2, 294-298.

Öztürk, A. (2002). Tarih Öğretiminde Tarihi Romanların Kullanılması. Yayınlanmamış Yüksek Lisans Tezi, Gazi Üniversitesi Eğitim Bilimleri Enstitüsü, Ankara.

Öztürk, C. ve Otluoğlu, R. (2005). Sosyal Bilgiler Öğretiminde Edebî Ürünler ve Yazıl Materyaller. Ankara: PegemA. 
Safran, M. (1993). Değişik Öğrenim Basamaklarında Tarih Dersine İlişkin Tutumlar Üzerine Bir Araştırma. Eğitim Dergisi, (4), 35-40.

Safran, M. ve Ata, B. (2003). Öğrencilerin Tarih Metinlerinden Anlam Çıkarmalarına Yönelik Araştırmalara Bir Bakış. C. Şahin (Ed.), Konu Alanı Ders Kitabı İnceleme Klavuzu Sosyal Bilgiler içinde (ss. 339-353.). Ankara: Gündüz Eğitim ve Yayıncılık.

Smith, J. A., Monson, J. A., \& Dobson, D. (1992). A Case Study on Integrating History and Reading Instruction through Literature. Social Education, 56(7), 370-375.

Şimşek, A. (2000). İlköğretim Sosyal Bilgiler Dersinin Öğretiminde Hikâye Anlatım Yönteminin (Storytelling) Kullanımı. Yayınlanmamış Yüksek Lisans Tezi, Gazi Üniversitesi Sosyal Bilimler Enstitüsü, Ankara.

Şimşek, A. (2004). İlköğretim Okulu Sosyal Bilgiler Dersi Tarih Konularının Öğretiminde Hikaye Anlatım Yönteminin Etkililiği. Türk Ĕ̆itim Bilimleri Dergisi, 2 (4), 495-509.

Şimşek, A. (2006a). İlköğretim Sosyal Bilgiler Dersinde Tarihsel Hikâyeye Yönelik Öğrenci Görüşleri. Gazi Üniversitesi Gazi Eğitim Fakültesi Dergisi, 26(1), 187-202.

Şimşek, A. (2006b). Bir Öğretim Materyali Olarak Tarihsel Romana Yönelik Öğrenci ve Öğretmen Görüssleri, TOJET, 5(4), 73-81.

Şimşek, A. (2006c). Tarihsel Romanın Eğitimsel İşlevi. Bilig Dergisi, 37, 65-8o.

Şimşek, A. (2010a). Tarih Öğretiminde Destanlar ve Efsaneler. M. Safran (Ed.), Tarih Nasıl Öğretilir içinde (ss. 258-263). İstanbul: Yeni İnsan.

Şimşek, A. (2010b). Tarih Öğretiminde Tarihsel Hikâye ve Roman. M. Safran (Ed.), Tarih Nasıl Ŏgretilir içinde (ss. 264-271). İstanbul: Yeni İnsan.

Şimşek, A. (2015). Sosyal Bilgiler Dersinde Bir Öğretim Materyali Olarak Edebi Ürünler. M. Safran (Ed.), Sosyal Bilgiler Öğretimi içinde (ss. 389-412). Ankara: Pegem A.

TDK (Türk Dil Kurumu). (1998). Türkçe Sözlük. Ankara: Türk Dil Kurumu.

Tekgöz, M. (2005). İlköğretim 7. Sinıf Sosyal Bilgiler Dersinde Edebiyat Temelli Öğretim Yönteminin Öğrencilerin Akademik Başarısına ve Kahıılı̆̆a Etkisi. Yayınlanmamış Yüksek Lisans Tezi, Çukurova Üniversitesi Üniversitesi Sosyal Bilimler Enstitüsü, Adana.

Tural, S. (1993a). Edebiyat Bilimine Katkılar. Ankara: Ecdâd.

Tural, S. (1993b). Tarihî Roman Geleneği veya Cezmî, Doğumunun Yüzellinci Yılında Namık Kemal içinde (ss. 67-91). Ankara, Atatürk Kültür Merkezi.

Tural, S. (2000). Tarihten Destana Akan Duyarlılık. Ankara: Atatürk Kültür Merkezi Başkanlığı.

Top, M. (2009). İlköğretim 8. Sinıf T.C. İnkılâp Tarihi ve Atatürkçülük Dersinin Öğretiminde Edeb̂̂ Ürünlerin Kullanımının Öğrenci Başarısı ve Tutumuna Etkisi. Yayınlanmamış Yüksek Lisans Tezi, Marmara Üniversitesi Eğitim Bilimleri Enstitüsü, İstanbul. 